\title{
Developing Sustainable Special Economic Zones in Botswana: A Conceptual Discussion
}

\author{
Edward E. Marandu \\ University of Botswana \\ Faculty of Business, Marketing Department \\ Donatus Amanze \\ University of Botswana \\ Faculty of Business, Marketing Department
}

\begin{abstract}
INTRODUCTION
The objective of this paper is to explore the concept of Special Economic Zones (SEZ) and suggest sustainable development strategy for Botswana. This objective is achieved through a five stage analysis of the literature. First, a brief description of the concept is made. Second, arguments in favour of externally oriented development strategies for Botswana are presented. Third, a description of the Botswana SEZs policy is attempted. Fourth, two theoretical frameworks, namely, Rostow's modernization theory and the international product life cycle (IPLC) are described. Finally on the basis of the above and related literature lessons or implications for appropriate SEZs in Botswana are presented.
\end{abstract}

\section{WHAT ARE SEZS?}

The term special economic zone (SEZ) is commonly used as a generic term to refer to a specially demarcated area within a nation that offers unique incentives to attract foreign and local direct investment. Special refers to the relaxation of economic laws and immigration policies applicable nationwide so as to benefit firms established within the area chosen as a SEZ. SEZ Authorities act as 'governments' and ruling authorities within the designated zones. There are different types of SEZs, for example, Export Processing Zones (EPZ), Free Enterprise Zones, Free Trade Zones, Free Ports, Science and Technology Park. SEZs companies are treated as operating from outside the country and their goods treated as imports.

\section{SPECIAL ECONOMIC ZONES IN BOTSWANA}

The Special Economic Zones policy adopted by the Government of Botswana (Republic of Botswana Ministry of Trade and Industry, 2010) is designed to attract world class domestic and foreign investors by offering them developed infrastructure, state of the art technology and economic incentives. The SEZs would be characterised by economic and other laws that are more free market oriented than that of typical Botswana national laws. SEZs are expected to provide tax and other incentives for boosting exports from Botswana. Specifically Botswana's SEZ policy seeks to establish an authority that would:

- Establish a one stop, full service business environment catering to the needs of businesses located within the SEZ

- Provide a hassle free business environment offering investors a competitive edge in world markets

- Identify locations for establishing SEZs

- Ensure basic infrastructure is in place

- Develop national and international programmes promoting SEZs 
- Coordinate SEZ investments

- Provide SEZ incentive packages consistent with Botswana's domestic and international trade obligations.

- Licence SEZ investors.

- Diversify the economic and export base of Botswana beyond the mining sector.

The government has decided to create eight specialized sectors called "hubs," which are currently at different stages of development (Figure 1). These are the Agricultural Hub, the Botswana Innovation Hub, the Minerals Hub, the Education Hub, the Health Hub, the Transport Hub and the Financial Services Hub. The aim of the Agricultural Hub is to transform arable and animal production to become a profitable commercial sector. The Botswana Innovation Hub's (BIH) broad objective is aimed at attracting technology-driven, knowledge intensive businesses. The Minerals Hub is charged with the responsibility of transforming Botswana from a leading rough diamond producer to a world centre for downstream diamond activities. The objective for the Education Hub is to develop Botswana into a regional centre of excellence for exporting educational services. The Health Hub was established with a view to make Botswana a centre of excellence in healthcare service provision. The purpose of the Transport Hub is to strengthen Botswana's transportation connectivity both internally and externally. The objective of the Financial Services Hub is to facilitate other sectors in terms of banking, investment services and insurance services.

Figure 1: Botswana SEZ Selected Areas

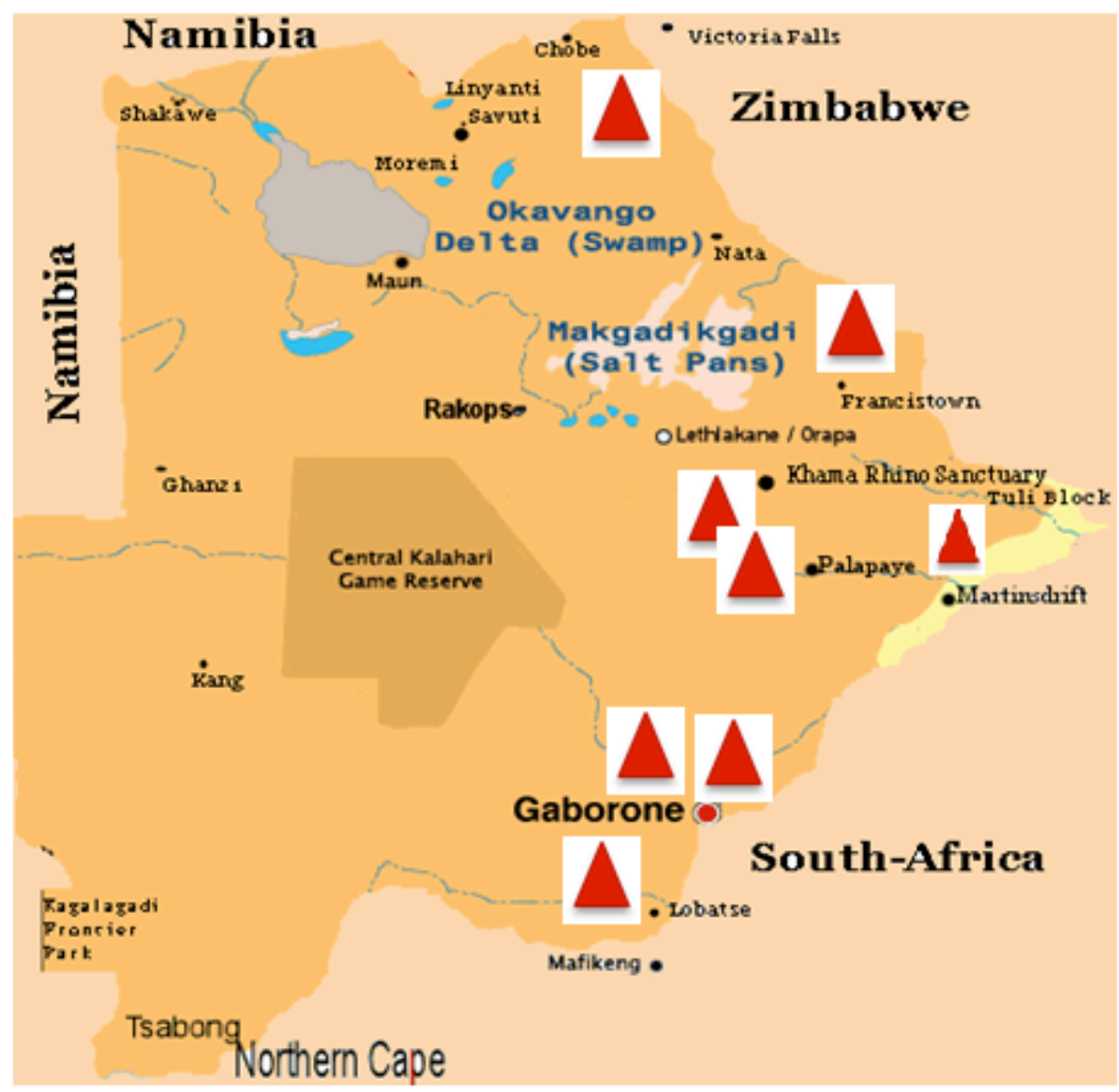




\section{IMPORTANCE OF EXPORT ORIENTED DEVELOPMENT}

There are three good reasons why it is vital for Botswana to practice outward looking export oriented development strategy: (1) it is an open economy (2) the need to diversify the export base and (3) the limited local market.

Botswana is an Open Economy: In Botswana external trade is an important component of the economy. The importance of external trade in an economy is measured by the degree of "openness" which is the magnitude of trade (exports plus imports) in relation to the GDP. This ratio was 72\% in 2015 in Botswana (Trading Economics, 2016). The ratio for India is 13\%; it is much lower than that of Botswana. That of the USA is $25 \%$. These figures suggest that India and the USA are relatively closed economies in the sense that they are relatively self-reliant. On the other end Botswana is an open economy in the sense that she is highly dependent on foreign trade.

The implication of the openness ratio is that the economy of Botswana is sensitive to economic conditions in the outside world. Hence changes in the prices or volumes of exports or imports are likely to have substantial effect on the performance of the whole economy. The 2008 global financial crisis attests to this. Botswana cannot afford to ignore what is happening in the rest of the world.

Need to Diversify the Export Base: Botswana's success story is based on exports and the base is unbalanced: it is dominated by diamonds which accounts for more than about 80 percent of exports. The recent global financial crisis has revealed that this commodity is highly vulnerable to external shocks. It goes without saying that there is need to diversify the export base in order to reduce the risk of over-reliance on one commodity.

Limited Local Market: The domestic economy is too small to thrive on its own (Khama, 2010). Botswana has a relatively small population, estimated at 1.8 million in 2009 . This imposes a severe limit to growth because of a limited local market. This constraint means that the envisaged diversification must be mainly externally oriented. In deed the externally oriented diversification strategy has been found by many small emergent economies such as South Korea, Hong Kong, Singapore and Taiwan to be an effective means of achieving rapid economic growth.

The search for ways to diversify the export sector in order to promote sustainable development is a major policy issue in Botswana today. In order to diversify the export base, at least three broad policy options can be considered in the context of Botswana (Marandu, 2006).

Import Substitution Industrialisation: The first is import substitution strategy; that is, the domestic production of that which would have been imported. The advantage of this strategy is that it is less risky, for the businessperson plans for an assured domestic market. The problem with import substitution is that the choice of industries must be consistent with a country's comparative advantage.

Export-led Manufacturing Industrialization: The second method for diversifying is through export expansion rather than import substitution. Proponents of this strategy argue that export expansion is an outward looking strategy and holds better prospects for long-term growth than inward looking import substitution strategy, partly because it discourages misallocation of resources. Outward-looking theorists claim that an inward-looking country will stagnate and lose the dynamic benefits of trade (Goff, 2003). On the other hand inward- 
looking theorists suggest that a country is doomed to providing low-growth primary products for developed countries if it remains fully open to trade. They argue that there is no assurance that an export-led strategy will perform well in the short-term because of market and supply constraints. Furthermore, they argue that, even the outward looking export orientated countries such as Japan and Chile undertook a certain degree of inward-looking policies protection (Essays...., 2006).

The debate between export-led and import substitution strategies has not been settled one way or the other. It is possible for a developing country to mix policies. For example, maintaining an outward-looking policy on trade in primary products but an inward-looking one for secondary products as it tries to nurture infant industries. Others argue that these countries in fact pursued mixtures of policies targeted at specific industries.

Moreover, it is becoming increasingly evident that the choice of an inward or outward looking strategy depends on conditions of the country in question. For instance, large countries with large markets may try, with some success, an inward looking strategy. On the other hand small countries with limited markets are more likely to succeed if they follow outward looking development strategies. The success of outward looking strategies by the small Newly Industrialising Countries of Korea, Hong Kong, Singapore and Taiwan are examples, which support this line of reasoning.

Export of Services: Tourism is currently Botswana's most rapidly growing sector and contributes $15.9 \%$ of its gross domestic product (GDP). The government's tourism policy emphasises the promotion of environmentally sensitive, low-volume, high-cost tourism. A diversification strategy could be developed to accelerate and take advantage of this growing service sector.

The various strategies are not mutually exclusive and can be pursed simultaneously. At any one point in time the country may emphasise one or the other. This study is mainly concerned with the export strategy. In order to diversify the exports base by using conscious strategies, policy makers need to understand the obstacles to exports in Botswana. This study aims at making a contribution toward that end by focusing on obstacles to exports by manufacturing firms.

\section{SPECIAL ECONOMIC ZONES AND THEORY}

The aim of this section is to present theoretical models which can assist policy maker in evaluating the suitability of the various SEZs in a local context. In accomplishing this, we conducted a scan of the literature, to identify a suitable theoretical framework for understanding modernization of nations. The literature scan identified two theories: The Rostow Model of Development and the International Product Life Cycle Theory. The two theories facilitate understanding of appropriate SEZs in a specific situation.

\section{The Stages of Development Model}

The Stages of Development Model was created in 1960 (Rostow, 1960). The model suggests that developed countries have tended to pass through five linear stages (Figure 2) to reach their current degree of economic development. These are:

1. Traditional society. This earliest stage is characterized by heavy dependence on "primary sector" activities. Production is characterized by being subsistence, labour intensive, limited technology, low productivity in agriculture or hunting or gathering. 
The outputs are consumed by the producers, very little of which is saved or traded and the only trade that exists is barter trade of items needed for subsistence, not done for profit. Other than the land for food production there is limited exploitation of raw materials and so the development of other industries is also restricted.

Figure 2: Stages of Economic Development

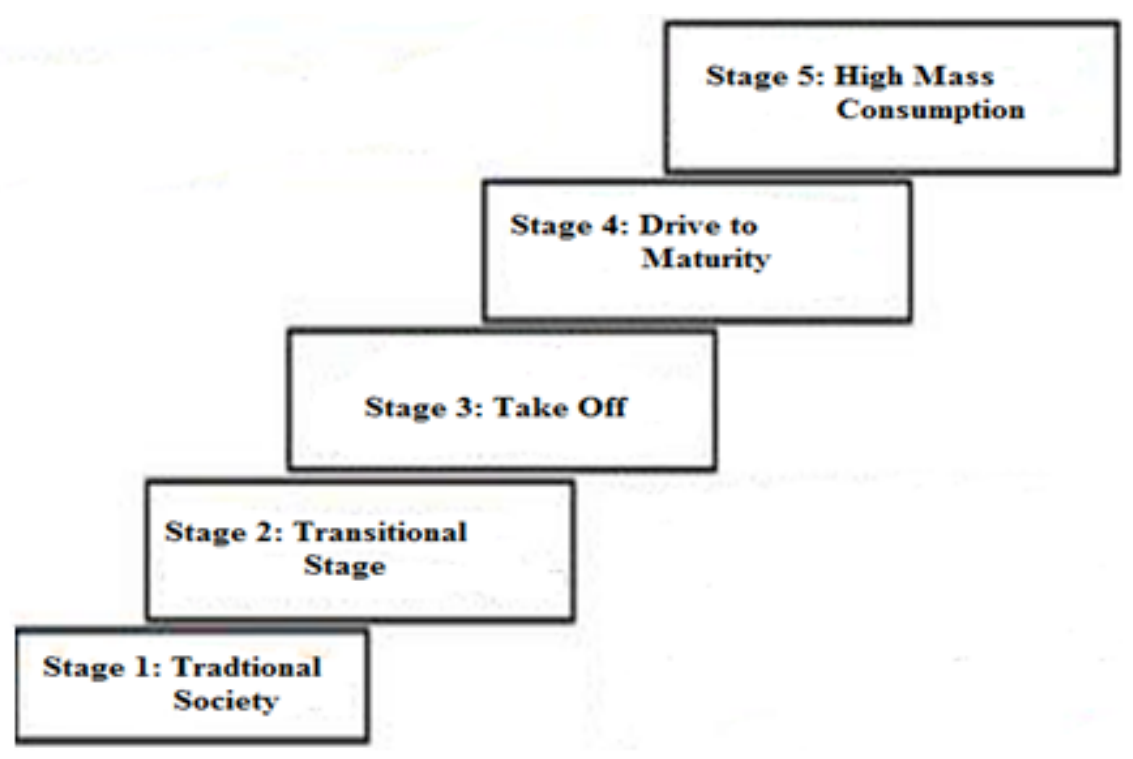

2. Pre-conditions for take-off. In the second stage agriculture becomes more mechanised resulting in more output for trading. Savings and investment grow although they are still a small percentage of national income. Other industries start to emerge although one will take dominance (this is usually textiles) and resources start to be exploited. The sources of the finance are normally from external demand for raw materials, overseas aid, foreign direct investment or remittance income from migrant workers living overseas.

3. Take-off. In the third stage manufacturing industry assumes greater importance, although the number of industries still remains small. Political and social institutions start to be transformed to help maintain a steady rate of growth. Savings and investment grow, perhaps to $15 \%$ of national income. External finance may still be required. Agriculture assumes lesser importance in relative terms although the majority of people may remain employed in the farming sector. There is often a dual economy apparent with rising productivity and wealth in manufacturing and other industries contrasted with stubbornly low productivity and real incomes in rural agriculture.

4. Drive to maturity. In the fourth phase growth becomes self-sustaining as the economy moves away from being dependent on primary factor inputs for growth towards making better use of innovation to bring about increases in real per capita incomes. Industry becomes more diverse resulting in goods being produced at home instead of being imported. New import requirements and new export commodities develop, resulting in an economy which forms a part of the international market. The most advanced technology available is used by all economic activities and between 10 and 20 percent of national income is invested. Growth spreads to different parts of the country as the state of technology improves.

5. Age of mass consumption. In the final stage as output levels grow, it enables increased consumer expenditure. During this phase emphasis is given to consumer durables and services that allow the majority of a country's population to attain a relatively high standard of living. The initially exploitative "primary" industries move elsewhere as the 
remaining industries shift production to durable consumer goods and services. There is a shift towards "tertiary sector" activity. One of the main shifts that occur as a country moves through the five stages is within the industry sector as activity shifts from primary, secondary and tertiary sectors; and the changes that happen here get reflected in the employment sector (Table 1).

Table 1: The Stages Model and Changes in Industry and Employment

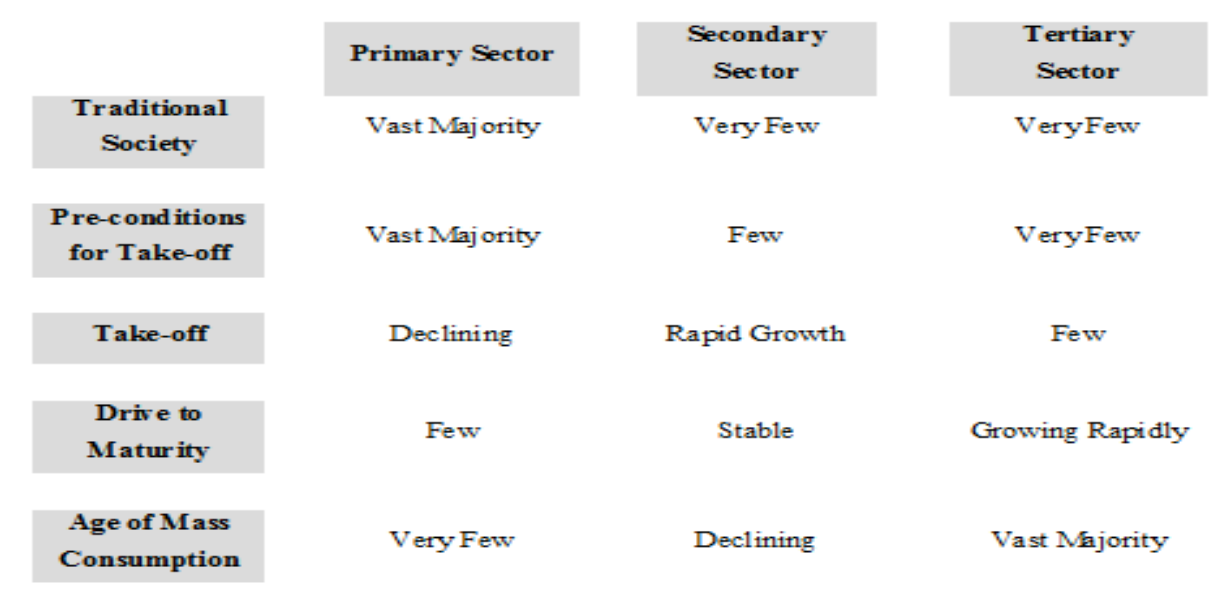

\section{Implications of the Stages Theory for Investment}

In general, the goods, services and investment needed by a country in an earlier stage of economic development are different from the goods and services required in later stages as follows. People in less developed countries place more emphasis on utility (basic product) and place relatively little value on aesthetic (beauty, extras) as much as do people in the more developed nations. A less developed country may need to import industrial machinery and equipment to exploit its raw materials and to produce agricultural products, as well as basic construction equipment to develop a transportation system. It may need management consulting, accounting systems, and training and development services.

When the country becomes fairly well industrialized, producing capital and consumer goods such as machinery, automobiles, and refrigerators, it may need more specialized and heavy capital equipment not yet manufactured there. For example, a country producing automobiles may need more modern equipment, such as wheel alignment indicators.

In the fifth stage, a country reaches complete industrialization. Even though a country may be totally industrialized, a demand for goods from another country still exists, because highly industrialized countries tend to specialize in the production of certain goods. For example, U.S. enterprises are highly skilled in producing communications and sophisticated computer technologies, and Japanese enterprises are highly skilled in producing process technologies.

\section{International Product Life Cycle (IPLC)}

Another theory helpful in understanding appropriate policies for SEZ is the International Product Life Cycle (Vernon, 1966; Igal, 1981). It is useful as an explanation of who produces what and why. It is simple and persuasive. Briefly the Life Cycle Theory assumes that in general, trade in manufactured goods typically follows a cycle with four main phases: Introduction, Growth, Maturity and Decline (Figure 3). 
Introduction: The introduction stage is marked by innovation, production, and sales in same country. During the early stages of the cycle a product is first produced in the country which has discovered it. The new product is for use in the local market and for export. In this early stage of the cycle, comparative advantage rests with the innovating country because of "technological gap" between the innovating country Vis-a'-Vis the others places the innovating country in a monopoly position. In the initial phase of the cycle, usually, manufacturing occurs in a developed country, such as the US, where the innovator is motivated by a potentially profitable market.

Growth: In phase two, growth of demand in the importing nations may provide sufficient volume to justify local manufacture. As production begins abroad, the exports of the initiating nation grow less rapidly because other producing countries take a share of the market in their own country and other export markets. In the second phase of the cycle, usually manufacturing occurs in other advanced countries, say in Europe.

Maturity: The third stage occurs as the product matures. A mature product uses an already established technology and a lower skilled labor content. In this situation, the less developed countries may be able to undersell the more advanced countries by applying their cheap lessskilled labor to the technology already designed to product. Thus the less developed nations may become attractive production points and begin exporting the product to more advanced countries. Examples of products which are in this latter stage are textiles and electronic components.

Decline: The Decline stage is characterized by concentration of production in emerging economies. The innovating country becomes a net importer of the product it innovated in the first place. This means that comparative advantage shifts from one nation to another as a product matures.

Figure 3: PLC of Different Countries for a Specific Product

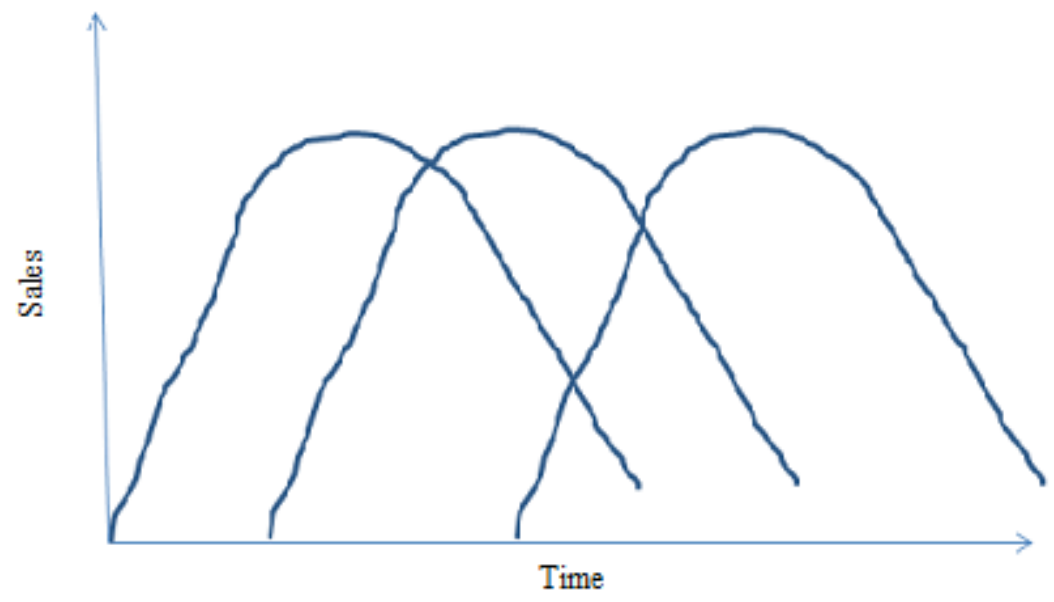

\section{POLICY LESSONS AND SUGGESTIONS}

The theoretical literature reviewed leads to the following implications for advising policy makers interested in creating sustainable SEZs in Botswana. Botswana has the potential to derive benefits from special economic zones. The country is in need of diversification and it is in the early stage of industrialization. To diversify, the country needs to attract private investment. SEZs can support diversification in the country if they are implemented effectively by overcoming infrastructure constraints and taking advantage of economies of scale within SADC and SACU trade preferences. Thus, there is a good argument in support of SEZs as a 
policy instrument for diversification, but not an unconditional support. There are certain preconditions for successful implementation of a zone programme in the country:-

\section{Attract Export Oriented Firms}

Botswana should strive to attract into the SEZ firms that export the bulk of their output to be exported to foreign markets, as opposed to import substitution SEZ that sell a bulk of their output to the local economy. The domestic market is too small for sustained growth. This policy is consistent with the SEZs that were part of an export oriented strategy that has characterized many Asian economies since World War II. In fact Japan was the first to develop such a strategy in the region.

To attract investors the following incentives should be considered for offering to foreign investors. Labour: The ability to use the Batswana vast pool of low cost unemployed labour may be promoted as a powerful incentive to locate in the proposed SEZs. In addition the firms should be given the liberty to hire and fire labour, which is different from the prevailing lifetime permanent and pensionable system or collective bargaining. Land: The SEZs should be physically developed as planned entities with infrastructures and access to a container dry port complex so that parts and raw material could easily be brought in for processing and shipped to foreign markets. Since Botswana is a landlocked country, accessibility to port infrastructures of neighbouring countries with such facilities should be a dominant factor in the planning of sustainable SEZs strategy. Tax incentives: Custom duties should not be levied on imported materials and parts as long as they are for re-export.

\section{Which Export Oriented Industries to Attract?}

In order for the zones to be sustainable, the zone programmes must be based on Botswana's comparative advantages. With this in mind we can speculate on three industries that the country may be advised to promote under the SEZ model because the nation has comparative advantage in them:

i. The first is land-intensive natural-resource-based sectors (mining) and agriculture (leather industries) in the short term. Their potential is in increasing beneficiation through processing activities that are one stage or more downstream from production. The manufacturing or processing, activities that are envisaged should be focused on sectors in which Botswana has comparative advantage in inputs. Focusing zones around these sectors increases the likelihood of local economy capturing the spillovers from foreign direct investment by creating zone linkages with the local economy through integrating local raw materials and intermediate inputs. In fact one of the reasons for failure of several African zones has been identified as tendency to become enclave economies, without development of backward and forward linkage industries with the local economy (Centre for Education and Documentation, 2009).

ii. The second which the country has comparative advantage is the development of Botswana as an important touristic destination for domestic, regional and international tourism. In pursuing this, one must bear in mind that Botswana suffers from several disadvantages in regard to air connections with Europe and other source markets.

iii. The third is transforming Botswana into a transportation hub for transit cargo and passengers by enhancing connectivity with neighboring Zambia, Namibia, Zimbabwe, Angola and South Africa. The strategy should aim at developing efficient cross-border road and rail transport linkages. The plan may involve long-term removal of road damaging trucks from neighboring countries by operating regional railway system that carries goods to a dry port on the Botswana border. This will reduce the number of 
foreign trucks that cause damage and accidents on the roads and increase the amount of money collected as transport charges by Botswana.

\section{Take into account the Stage of Economic Development.}

Goods and services needed by a country vary by stage of economic development; hence the kind of SEZ promoted by Botswana and the level of incentives used must be appropriate for the level. With regard to type of SEZ, since the stages model assumes nations go through the stages sequentially, this implies that the type of investments to be promoted in Botswana should be those that will propel the nation into the next stage. Botswana has not yet reached the take-off stage. Industrialization has not yet taken a centre stage in the economy which is still dominated by natural resources, mainly minerals. Infrastructure shortcomings continue to represent a significant obstacle to improvement in productivity in Botswana. However the cheap labour in the country as well as the generous incentives provides opportunity for industrial FDI to flow into the country that would help diversify the economy from natural resource based economy to a more industrialized one. With regard to the level of incentives, tax concessions to investors should be considerably more generous during the lower stages compared with those during higher stages of development.

\section{Take into account the products' stage in the International Product Life Cycle.}

In planning SEZs it is important to take cognizant of two aspects in relation to the general stage of the life cycle of the products or services to be promoted. First, the stage of a product on the life cycle is normally different in different export markets. That is, a product that is new in one export market may be out-of-date in another market. There is saying in which says: "Yesterday's product in the USA is today's product in the UK and tomorrow's product in Africa". Second, the PLC theory assumes by implication that products in the later stage of the cycle utilize inputs which are relatively abundant in developing countries. This may be misleading. A distinction must be made between labour intensive mature products and capital intensive mature products. It is the former type of products which are more consistent with the comparative advantage of developing countries.

The theory therefore suggests that the zones in Botswana should focus on labour intensive, mature industries such as textiles, leather goods and building materials. This recommendation is consistent with the observation that "comparative advantage shifts from one nation to another as a product matures". In deed this is what is happening currently in China. Labour costs in China have risen faster than consumer inflation for years, and are currently nearly four times those in Bangladesh, Laos, Cambodia and Myanmar (Magnier, 2016). China is now losing low-end manufacturing to lower labour especially textile and clothing manufacturing.

\section{Avoid the Race to the Bottom}

In competing for FDI Botswana should avoid the so-called "race to the bottom" syndrome whereby SEZ costs, in terms of the various concessions granted to investors, outweigh their benefits. Nobody wins a race to the bottom. The government should periodically make a costbenefit analysis of SEZs investment. It should be noted that the government is likely to make substantial investment in infrastructure and provide a variety of tax concessions to the firms in the zones. One must compare these costs with achievement of the purposes for which the SEZs were founded such as earning revenues and foreign exchange and creating employment. Does the contribution of the SEZs to the country justify the investments? Or could the resources have been utilized better in the economy?

Host nations engaging in promoting FDI through aggressive financial concessions believe that investors are highly economic-sensitive. They offer more of the same as competitors. Botswana 
should consider promoting FDI through differentiation by focusing on it being a peaceful, stable democracy on the continent. This can be a powerful incentive especially in this period when terrorism threatens global development.

\section{SEZs are a Transitory Policy Instrument}

The theories of "Stage of Economic Development" and the "International Product Life Cycle" imply that SEZs are effective only as transitory policy instruments during the first phases of industrialization and implementation of export-led growth strategies. SEZs are attractive to investors because of the existence of policy failures in the host country; as liberalization continues investors will see no need for staying in the SEZs. As countries achieve higher levels of economic development and income, the relative significance of EPZ in economic terms can be expected to decline.

Thus, Botswana's export-led growth strategies cannot rely solely on SEZs to achieve higher levels of economic growth in the long-term. The country should acknowledge the transitional aspect of SEZs, and manage wisely the opportunities they may bring to upgrade labour and managerial skills, acquire superior technology and access foreign markets. In other words, SEZ should be a part of a more extensive package of polices aimed at improving the international competitiveness (Jenkins, Esquivel, \& Felipe, 1998). For example, establishing an export processing zone in an economy that has already reformed its macroeconomic policies is not recommended on two grounds: (1) Low FDI flows may be due to inadequate legal or regulatory framework or economic incentives in other areas of the economy (for instance: private property or labour laws) and (2) SEZs are distortionary economic policy instruments and will re-introduce an element of discretion into the policy environment. Successfully incorporating SEZs into the national economy will require periodic revisions of the SEZ laws to accommodate changing national economic conditions. On the other hand, domestic reforms should be formulated so that eventually the same incentives and benefits apply to all firms.

\section{The Role of Government}

The whole discussion in this paper suggests or implies that SEZs are effective in countries with strong state involvement. The commitment at the highest level of government to comprehensive export-driven growth policies is a precondition for success of the SEZs policy in Botswana. The policy requires commitment of funds to a massive development programme. When the government does not have the money it can look out for potential private partners who are willing to invest in that area; thus a win-win situation for both.

\section{References}

Centre for Education and Documentation. (2009, July 1). Centre for Education and Documentation. Retrieved October 10, 2016, from The Impact of Special Economic Zones on Small Farmers in India: http://base.d-ph.info/en/fiches/dph/fiche-dph-7976.html

Essays.... (2006). is there a role for protection in developing countries? If so, should it be by tariffs or subsidies? Retrieved January 26, 2006, from http:// www.mapeters.fsnet.co.uk/Essays/ec503c.htrn.

Goff, P. (2003). Development strategies. Development Economics Web Guide, 30(1).

Igal, A. (1981). International Product Life Cycle: A Reassessment and Product Policy Implications. Journal of Marketing, 45(4), 91-96.

Jenkins, M., Esquivel, G., \& Felipe, L. B. (1998). Export Processing Zones in Central America Discussion Paper No. 646. Havard Institute for International Development.

Khama, S. I. (2010). State of the Nation Address by His Excellency Lt. Gen.Seretse Khama Ian Khama, President of the Republic of Botswana, to the Second Session of the Tenth Parliament - "Delivering People Centred

Development". Gaborone: Government of Botswana. 
Magnier, M. (2016, July 7). Wall Street Journal. Retrieved September 18, 2016, from Business:

http://www.wsj.com/articles/how-china-is-changing-its-manufacturing-strategy-1465351382

Marandu, E. E. (2006). Perceived Obstacles to Exporting by Manufacturing Firms In Botswana. BIAC Journal, 3(2), 24-47.

Republic of Botswana Ministry of Trade and Industry. (2010). Special Economic Zones Policy for Botswana: Industrialization, Diversification and Export Development for Global Competitiveness. Gaborone: Governnment Publisher.

Rostow, W. W. (1960). The stages of economic growth: A non-communist manifesto. Cambridge: Cambridge.

Trading Economics. (2016, October 12). Trading Economics. Retrieved November 4, 2016, from Trading Economics: http://www.tradingeconomics.com/botswana/gdp; http://www.tradingeconomics.com/botswana/exports

Vernon, R. (1966). International investment and international trade in the product cycle. The quarterly journal of economics, 190-207. 